\title{
Zarzio $^{\circledR}$, biosimilar of filgrastim, in prophylaxis of chemotherapy-induced neutropenia in routine practice: a French prospective multicentric study
}

\author{
Sophie Nahon ${ }^{1} \cdot$ Mansour Rastkhah $^{2} \cdot$ Meher Ben Abdelghani $^{3}$. \\ Ravaka-Fatoma Soumoudronga $^{4} \cdot$ Isabelle Gasnereau $^{4}$ • Jean-Luc Labourey ${ }^{5}$
}

Received: 24 June 2015 / Accepted: 9 October 2015 / Published online: 27 October 2015

(C) The Author(s) 2015. This article is published with open access at Springerlink.com

\begin{abstract}
Purpose Chemotherapy-induced neutropenia is a serious and potentially life-threatening consequence of cancer treatment. Prophylactic treatment with granulocyte-colony stimulating factor (G-CSF) decreases the incidence of febrile neutropenia, the rate of hospitalization, and the use of antibiotics in patients at risk. The aim of this study was to assess efficacy, safety, and use of Zarzio ${ }^{\circledR}$ _biosimilar of Neupogen ${ }^{\circledR}$ (G-CSF; filgrastim) - in prophylaxis of chemotherapy-induced neutropenia in current practice in cancer patients.

Methods We conducted an observational, prospective, longitudinal, and multicentric study in France. The incidence of neutropenia was evaluated at each cycle of chemotherapy.

Results One hundred eighty-four patients (women, $64.7 \%$; mean age, 61.7 years) with solid tumor $(89.7 \%$; breast cancer, $50.5 \%)$ or non-Hodgkin lymphoma $(10.3 \%)$ were included. The risk of febrile neutropenia based on chemotherapy regimen was $>20 \%$ for $32.1 \%$ of patients. No case of febrile neutropenia was reported. Neutropenia was the cause of hospitalization and/or antibiotic therapy in 10 patients. The most frequent adverse events related to Zarzio ${ }^{\circledR}$ were pain, in particular bone pain. No serious adverse event related to Zarzio ${ }^{\circledR}$ was reported.
\end{abstract}

Isabelle Gasnereau

isabelle.gasnereau@sandoz.com

1 Centre Hospitalier du Pays d'Aix, Aix-en-Provence, France

2 Centre d'Hémato-Cancérologie Praz-Coutant, Passy, France

3 Centre Paul Strauss, Strasbourg, France

4 Sandoz Biopharmaceuticals, 49, Avenue Georges Pompidou, 92593 Levallois-Perret, Cedex, France

5 Centre Hospitalier, Carcassonne, France
Conclusion The results obtained in real-life conditions confirm that Zarzio ${ }^{\circledR}$ is efficient and well tolerated in cancer patients.

Keywords Chemotherapy-induced neutropenia · Filgrastim • Biosimilar $\cdot$ Observational study $\cdot$ Zarzio $^{\circledR}$

\section{Introduction}

Chemotherapy-induced neutropenia is a serious and potentially life-threatening consequence of cancer treatment because sepsis or severe infections are possible complications; neutropenia is generally observed during the first cycles of chemotherapy [1-6]. Moreover, delays and dose reductions of chemotherapy due to neutropenia in subsequent treatment cycles compromise efficacy [7-11].

Prophylactic administration of antibiotics significantly reduces the incidence of febrile neutropenia and mortality related to infections [12]. Antibiotic prophylaxis to prevent infection and infection-related complications in cancer patients at risk of febrile neutropenia is however controversial due to possible emergence of antibiotic resistance. The guidelines of the European Organization for Research and Treatment of Cancer (EORTC) do not recommend systematic administration of prophylactic administration of antibiotics [13]. An alternative approach is the prophylactic treatment with granulocyte-colony stimulating factor (G-CSF; filgrastim, lenograstim, pegfilgrastim) which decreases the incidence of febrile neutropenia, the rate of hospitalization, and the use of antibiotics in patients at risk [14].

The use of G-CSF in the prevention of chemotherapyinduced febrile neutropenia has been defined in different international guidelines. The guidelines of the American Society of Oncology (ASCO) in 2006 and those of the 
National Comprehensive Cancer Network (NCCN) in 2014 recommend the use of G-CSF in primary prophylaxis for chemotherapy associated with a risk of febrile neutropenia $\geq 20 \%[15,16]$. The 2006 guidelines of EORTC updated in 2010 recommend the systematic use of G-CSF in primary prophylaxis to prevent febrile neutropenia if the risk of febrile neutropenia associated with the cytotoxic chemotherapy is $\geq 20 \%$, but also on a case-by-case basis if the cytotoxic chemotherapy induces a risk from 10 to $20 \%$ [13]. In this case, the recommendations take into account patient-related risk factors that may increase the overall risk of febrile neutropenia such as age above 65 years.

Zarzio $^{\circledR}$ is a biosimilar of filgrastim (Neupogen ${ }^{\circledR}$ ). This biosimilarity has been demonstrated in analytical tests that assessed the physicochemical and biological characteristics of Zarzio ${ }^{\circledR}$ [17], in four phase I studies in 146 healthy volunteers and in a confirmatory phase III study for clinical efficacy in 176 patients with breast cancer [18]. Moreover, a retrospective study comparing the efficacy of Zarzio ${ }^{\circledR}$ to a historical cohort treated with Neupogen ${ }^{\circledR}$ [19] and an observational study [20] in patients with solid tumor or hematological cancer demonstrated that Zarzio ${ }^{\circledR}$ prevented chemotherapy-induced febrile neutropenia in ambulatory care, without unexpected adverse events. Few data were however available on the use of this biosimilar of filgrastim outside the controlled experimental environment of clinical trials. The objective of the present study was (1) to improve knowledge on Zarzio ${ }^{\circledR}$ for efficacy and safety in real-world conditions and (2) to understand how clinicians use Zarzio ${ }^{\circledR}$ in their clinical practice for the prophylaxis of chemotherapy-induced neutropenia.

\section{Patients and methods}

\section{Study design}

The Zarzio ${ }^{\circledR}$ Observational Study (ZOS) was an observational, prospective, longitudinal, and multicenter study, performed in French cancer centers. The objective of the study was to describe the prophylactic effect of Zarzio ${ }^{\circledR}$ on the incidence of severe neutropenia $(<500$ neutrophils/ $\mathrm{mm}^{3}$ ) and to collect data on safety and conditions of use in current clinical practice. The prescription of Zarzio ${ }^{\circledR}$ to a patient was independent of the inclusion of this patient in the study. The follow-up of each patient was a maximum of 6 cycles.

\section{Inclusion criteria}

Patients of both genders included in the study were aged of 18 years and older, received first-line chemotherapy for solid tumor or non-Hodgkin lymphoma with a performance index $\leq$
3, and were treated with Zarzio ${ }^{\circledR}$ with either a risk of febrile neutropenia $>20 \%$ or between 10 and $20 \%$ with patientrelated risks of febrile neutropenia as described by EORTC. Female patients must be postmenopausal for at least 1 year, sterile, or used efficient contraception. The main exclusion criteria were as follows: patient with grade 3 or 4 neutropenia (neutrophils $<1 \times 10^{9} / \mathrm{L}$ or $1000 / \mathrm{mm}^{3}$ ), myeloid leukemia, hypersensitivity to Zarzio ${ }^{\circledR}$ or to any other G-CSF, hypersensitivity to Escherichia coli-derived proteins or treatment by chemotherapy at high doses.

The patients were informed both orally and in writing on the objectives of the study. This study was conducted according to the current revision of the 1964 Helsinki declaration and with the French laws and regulations.

\section{Data collected}

Data of each patient were collected in an electronic case report form by the study physicians: sociodemographic data of investigator and patient, characteristics of cancer disease, number of chemotherapy treatments, type of chemotherapy, total scheduled dose and total administered dose, scheduled interval between chemotherapy cycles, risk factors of chemotherapy-induced neutropenia, number of neutrophils during follow-up, adverse events, clinical and biological data, treatment with Zarzio ${ }^{\circledR}$ (date of onset, duration of treatment, and dosage), episodes of febrile neutropenia, and use of antibiotics. Data were collected at each cycle of chemotherapy.

\section{Statistical analysis}

The primary endpoint of the study was the comparison of the incidence of severe neutropenia at nadir between the 1 st and the 4th cycle under treatment with Zarzio ${ }^{\circledR}$. The expected incidence of severe neutropenia (grade 4: $<500$ neutrophils $/ \mathrm{mm}^{3}$ ) at nadir was approximately $40 \%$ for the 1 st cycle of chemotherapy and $25 \%$ for the 4 th cycle [12]. In order to detect a decrease of $15 \%$ of the incidence of severe neutropenia with an alpha-risk at $5 \%$ and a statistical power at $80 \%, 150$ patients were needed. With a rate of $20 \%$ of non evaluable patients, 200 patients must be included. This analysis could not be performed due to the lack of data on neutrophil rates at nadir. This study allowed nevertheless collecting data on efficacy, safety and conditions of use of Zarzio ${ }^{\circledR}$. Clinical and hematological parameters during the follow-up were analyzed in the population of patients treated with Zarzio ${ }^{\circledR}$.

The relative dose intensity (RDI) was calculated at each cycle (total dose of chemotherapy administered during a cycle divided by the total dose scheduled for the same cycle). 


\section{Results}

\section{Characteristics of study physicians}

Among the 14 study physicians, 9 were male and they had a median of 18 years of practice (from 3 to 36 years). Nine practiced in general/university hospitals, 3 in specialized cancer centers, and 2 in private clinics. About the use of GCSF in chemotherapy-induced neutropenia, 11 out 14 reported to refer to the guidelines of EORTC, and the 3 other physicians referred to ASCO recommendations.

\section{Disposition of patients}

Figure 1 summarizes the disposition of the 184 patients included in the study during the chemotherapy cycles and, among them, those who received Zarzio ${ }^{\circledR}$. The median duration of follow-up of patients was 110 days (range from 28 to 243 days). A total of 32 patients (17.4\%) discontinued the study, most frequently due to disease progression.

\section{Characteristics of patients}

The characteristics of the 184 patients at inclusion are described in Table 1 . The study population had a median age of 64 years, and two-third were women. Chemotherapy was administered for solid tumor for $89.7 \%$ of patients, mainly breast cancer $(50.5 \%) ; 10.3 \%$ of patients $(19 / 184)$ had non-Hodgkin lymphoma. The median time interval between diagnosis and inclusion was 1.7 months, and mean was 10.2 months.
Among patients with solid tumor, tumoral stage was $\mathrm{T} 3$ for $20.1 \%$ and T4 for $11.0 \%$; there was stage N1 or more of lymph node involvement for $52.1 \%$ (85/163), and $20.2 \%$ (33/ 163) had metastases (stage M1). Nineteen patients among the 33 stage M1 patients had a metastatic relapse that was diagnosed with a median of 2.1 months before inclusion. Among patients with non-Hodgkin lymphoma, $42.1 \%(8 / 19)$ achieved stage IV (classification of Ann Arbor).

\section{Risk factors of neutropenia}

The risk factors of febrile neutropenia were assessed before the first cycle of chemotherapy: $32.1 \%(59 / 184)$ of patients had a risk of febrile neutropenia $>20 \%$; $55.4 \%(102 / 184)$ of patients had a risk between 10 and $20 \%$, and for $12.5 \%$ (23/ 184 ), the risk was $<10 \%$ (Table 2). The patient-related risk factors increasing the overall risk of febrile neutropenia were as follows: age $>65$ years for $45 \%(82 / 184)$ of patients, concomitant at-risk diseases for $20 \%(36 / 184)$, and hemoglobin< $12 \mathrm{~g} / \mathrm{dL}$ for $25 \%$ (46/184). Among the patients with a risk of febrile neutropenia $<10 \%, 9 / 23$ had an age above 65 years, $6 /$ 23 had a concomitant at-risk disease, and 8/23 had hemoglobin $<12 \mathrm{~g} / \mathrm{dL}$ (Table 2).

\section{Cycles of chemotherapy}

For most patients, the scheduled number of cycles was between 3 and $6(96.2 \%$; 177/184) and, for the majority, 6 cycles were scheduled $(70.1 \% ; 129 / 184)$ (Table 1). Most frequently, the scheduled time interval between 2 cycles was 3 weeks $(78.3 \% ; 144 / 184)$.

Fig. 1 Disposition of patients

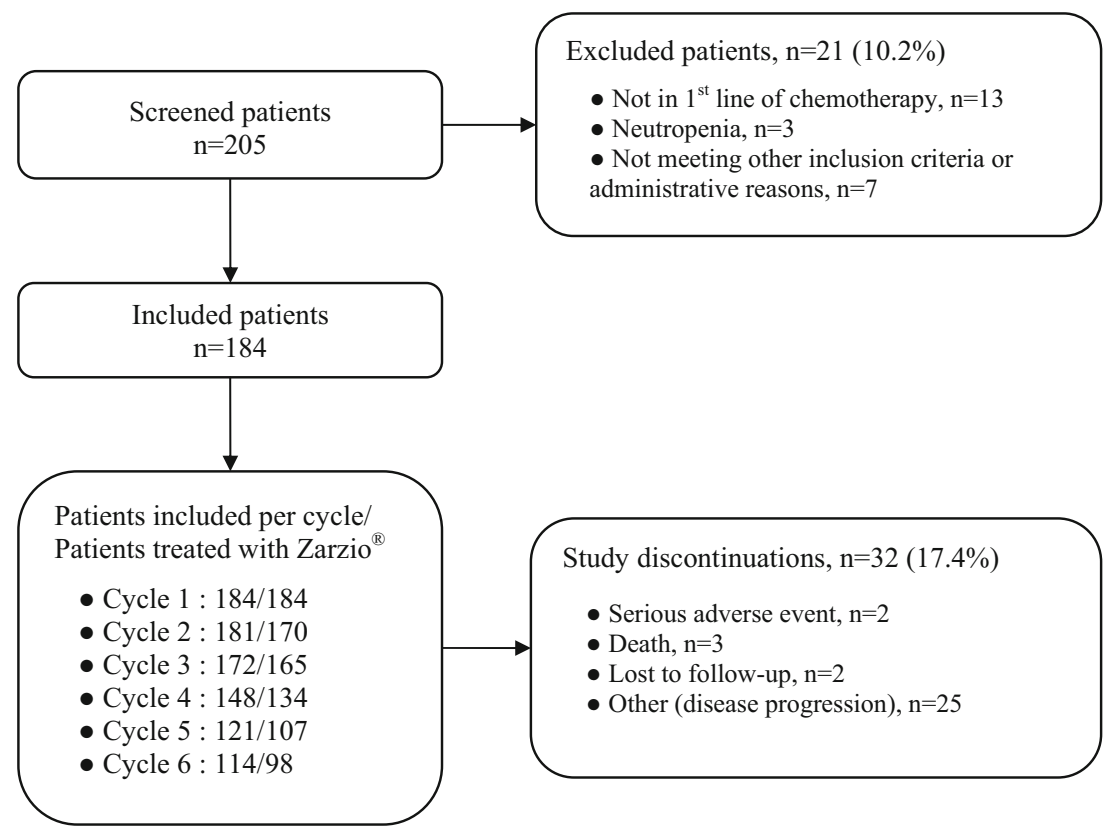


Table 1 Characteristics of patients at inclusion

\begin{tabular}{|c|c|}
\hline Characteristics & $N=184$ \\
\hline Female gender, $n(\%)$ & $119(64.7)$ \\
\hline \multicolumn{2}{|l|}{ Age, years } \\
\hline Mean (SD) & $61.7(11.6)$ \\
\hline Median (min-max) & $64.0(26-88)$ \\
\hline \multicolumn{2}{|l|}{ Body mass index, $\mathrm{kg} / \mathrm{m}^{2}$} \\
\hline Mean (SD) & $26.7(6.0)$ \\
\hline Median (min-max) & $25.8(16.5-50.6)$ \\
\hline \multicolumn{2}{|l|}{ Time interval since diagnosis, months } \\
\hline Mean (SD) & $10.2(30.0)$ \\
\hline Median (min-max) & $1.7(0-228)$ \\
\hline \multicolumn{2}{|l|}{ Type of primary tumor, $n(\%)$} \\
\hline Non-Hodgkin lymphoma & $19(10.3)$ \\
\hline Solid tumor & $165(89.7)$ \\
\hline Breast cancer & $93(50.5)$ \\
\hline Lung cancer & $13(7.1)$ \\
\hline Other solid tumor & $59(32.1)$ \\
\hline Patients with metastases (stage M1) & $33(20.2)^{*}$ \\
\hline Metastatic relapse, $n$ & 19 \\
\hline 1 site & 12 \\
\hline$\geq 2$ sites & 7 \\
\hline \multicolumn{2}{|l|}{ Metastatic sites, $\mathrm{n}$} \\
\hline Liver & 6 \\
\hline Lung & 5 \\
\hline Bone marrow & 2 \\
\hline Other & 14 \\
\hline \multicolumn{2}{|l|}{ Previous treatments, $n(\%)$} \\
\hline Radiotherapy & $27(14.7)$ \\
\hline Surgery & $98(53.3)$ \\
\hline Hormone therapy & $13(7.1)$ \\
\hline \multicolumn{2}{|c|}{ Number of planned chemotherapy cycles, $n(\%)$} \\
\hline 6 & $129(70.1)$ \\
\hline 4 & $21(11.4)$ \\
\hline 3 & $24(13.0)$ \\
\hline Other $(1,2,5,8)$ & $10(5.4)$ \\
\hline
\end{tabular}

*Two patients with missing data

The RDI administered for the included population varied from 96 to $99 \%$ between cycle 1 and cycle 6 ; the rate of patients with $\mathrm{RDI} \geq 85 \%$ varied from 89 to $99 \%$ between cycle 1 and cycle 6 .

A modification of chemotherapy protocol occurred for $47.8 \%$ of patients $(88 / 184)$ : decrease $>15 \%$ of scheduled dose $(29.5 \% ; 26 / 88)$, increase of the scheduled duration between 2 cycles $(70.5 \% ; 62 / 88)$, or change of the number of scheduled cycles $(35.2 \% ; 31 / 88)$.

Overall, chemotherapy began according to the initial schedule in $85.9 \%$ of cases. When it was not the case, neutropenia was responsible for this administration delay in $19.8 \%$ of cases.

Surgery of tumor was scheduled during chemotherapy for four patients (2.2\%) (during cycle 3 for the four patients). Radiotherapy was scheduled during at least one cycle for three patients (cycle 1; cycles 1 and 2; cycle 3 ).

\section{Treatment with Zarzio®}

Table 3 describes the conditions of administration and exposition to Zarzio ${ }^{\circledR}$ during the 6 chemotherapy cycles. The mean dose was stable during the 6 cycles (approximately $33 \mathrm{MIU}$ per day; median, 30 MIU per day) with a median number of 5 injections per cycle. The mean duration between the onset of chemotherapy cycle and the onset of Zarzio ${ }^{\circledR}$ administration varied from 3.6 to 4.5 days according to cycles (median, 3 days for each cycle); the mean duration of exposition to Zarzio ${ }^{\circledR}$ varied from 4.6 to 4.8 days (median, 5 days for each cycle). All injections were done by a nurse (and not by a physician or by the patient him/herself).

\section{Rates of neutrophils during the follow-up and chemotherapy-induced neutropenia}

The mean rates of neutrophils between cycle 1 and cycle 6 progressively decreased from 4584 to $3601 / \mathrm{mm}^{3}$ in patients treated with Zarzio (Table 4). This decrease mainly occurred after the first chemotherapy cycle and remained nearly stable for the next cycles. Accordingly, the rate of grade 1-2 neutropenia (1000-2000 neutrophils $/ \mathrm{mm}^{3}$ ) mostly increased after the first cycle: $5.6,20.5,16.1,24.4,23.4$, and $31.6 \%$ for each of the 6 successive cycles. Only one grade 4 neutropenia was observed (after cycle 1).

No case of febrile neutropenia was reported during the study. Neutropenia led to hospitalization and/or antibiotic treatment in 10 patients (hospitalization with antibiotic treatment, $n=2$; hospitalization without antibiotic treatment, $n=4$; antibiotic treatment without hospitalization, $n=4$ ).

\section{Other hematological and clinical parameters}

The clinical parameters (body mass index, temperature, performance status) remained stable during the study in the population of patients treated with Zarzio (Table 5).

As for neutrophils, the means of the other hematological parameters decreased between cycle 1 and cycle 6 in the population of patients treated with Zarzio: leucocytes from 7479 to $6137 / \mathrm{mm}^{3}$; lymphocytes from 1733 to $1330 / \mathrm{mm}^{3}$; and $\mathrm{Hb}$ from 12.8 to $11.2 \mathrm{~g} / \mathrm{dL}$ (Table 5). The rates of platelets remained relatively stable, from 279 to $266 \times 10^{9} / \mathrm{L}$. 
Table 2 Assessment of the risk of chemotherapy-induced febrile neutropenia and patient-related factors increasing this risk

\begin{tabular}{|c|c|c|c|c|}
\hline \multirow[t]{2}{*}{ Patient-related factors increasing the risk of febrile neutropenia } & \multicolumn{3}{|c|}{ Risk of febrile neutropenia, $n(\%)$} & \multirow[t]{2}{*}{ Total $(n=184)$} \\
\hline & $<10 \%(n=23)$ & $10-20 \%(n=102)$ & $>20 \%(n=59)$ & \\
\hline Age $>65$ years, $n(\%)$ & $9(39)$ & $43(42)$ & $30(51)$ & $82(45)$ \\
\hline Concomitant disease, $n(\%)$ & $6(26)$ & $17(17)$ & $13(22)$ & $36(20)$ \\
\hline Hepatic, $n$ & 0 & 5 & 3 & 8 \\
\hline Renal, $n$ & 0 & 1 & 0 & 1 \\
\hline Cardiovascular, $n$ & 1 & 9 & 1 & 11 \\
\hline Other, $n$ & 6 & 10 & 10 & 26 \\
\hline Hemoglobin $<12$ g/dL, $n(\%)$ & $8(35)$ & $22(22)$ & $16(27)$ & $46(25)$ \\
\hline No patient-related factors, $n(\%)$ & 0 & $20(20)$ & 0 & $20(11)$ \\
\hline
\end{tabular}

\section{Safety}

Overall, $15.8 \%$ (29/184) of patients had at least one adverse event related to Zarzio ${ }^{\circledR}$ according to the investigator's judgment. An analysis of each cycle showed that this rate progressively decreased throughout the 6 cycles: from $7.7 \%(14 / 181)$ during cycle 2 to $2.6 \%(3 / 114)$ during cycle 6 . The most frequent adverse event related to Zarzio ${ }^{\circledR}$ was pain, in particular bone pain ( $n=15$ patients).

There were three deaths due to cancer disease. Serious adverse events were reported for 2 patients $(1.1 \%)$; none of them was considered to be related to Zarzio ${ }^{\circledR}$ (one adverse event was related to chemotherapy and the other one was due to the general condition requiring chemotherapy discontinuation). The study was discontinued for these two patients.
One case of intolerance to Zarzio ${ }^{\circledR}$ (lingual edema) led to study discontinuation. Most of the other study discontinuations were related to disease progression (Fig. 1).

\section{Discussion}

The strength of this non-interventional study rests on the following points: a relatively large number of patients $(n=184)$ followed in the usual conditions of administration of Zarzio ${ }^{\circledR}$; a high percentage of patients with a risk of febrile neutropenia $>20 \%(32.1 \%)$ or between 10 and $20 \%$ (55.4\%); a high percentage of elderly patients ( $44.6 \%$ of patients $>65$ years); a low number of patients lost to follow-up (6.3\%); data on hematological parameters between each cycle with very few
Table 3 Administration of Zarzio $^{\circledR}$

\begin{tabular}{|c|c|c|c|c|c|c|}
\hline & Cycle 1 & Cycle 2 & Cycle 3 & $\begin{array}{l}\text { Cycle } 4 \\
N=134\end{array}$ & $\begin{array}{l}\text { Cycle } 5 \\
N=107\end{array}$ & $\begin{array}{l}\text { Cycle } 6 \\
N=98\end{array}$ \\
\hline & & & & & & \\
\hline \multicolumn{7}{|c|}{ Time interval between onset of chemotherapy and onset of Zarzio ${ }^{\circledR}$, days } \\
\hline Mean (SD) & $3.8(2.2)$ & $3.9(2.3)$ & $4.5(4.8)$ & $3.7(2.3)$ & $3.9(2.2)$ & $3.6(2.0)$ \\
\hline Median & 3.0 & 3.0 & 3.0 & 3.0 & 3.0 & 3.0 \\
\hline Range & $1-9$ & $1-9$ & $1-33$ & $1-9$ & $1-10$ & $0-8$ \\
\hline \multicolumn{7}{|c|}{ Dosage of Zarzio ${ }^{\circledR}$, MIU/day } \\
\hline Mean (SD) & $33.1(6.8)$ & $32.9(6.6)$ & $32.6(6.5)$ & $32.7(6.4)$ & $33.1(6.8)$ & $33.5(7.1)$ \\
\hline Median & 30.0 & 30.0 & 30.0 & 30.0 & 30.0 & 30.0 \\
\hline Range & $30-48$ & $30-48$ & $30-60$ & $30-48$ & $30-48$ & $30-48$ \\
\hline \multicolumn{7}{|c|}{ Number of injections of Zarzio ${ }^{\circledR}$} \\
\hline Mean (SD) & $4.7(1.2)$ & $4.8(1.2)$ & $4.7(1.2)$ & $4.6(1.4)$ & $4.5(1.3)$ & $4.5(1.3)$ \\
\hline Median & 5.0 & 5.0 & 5.0 & 5.0 & 5.0 & 5.0 \\
\hline Range & $2-7$ & $2-7$ & $2-7$ & $2-10$ & $2-8$ & $2-8$ \\
\hline \multicolumn{7}{|c|}{ Exposition to Zarzio ${ }^{\circledR}$, days } \\
\hline Mean (SD) & $4.8(1.3)$ & $4.8(1.3)$ & $4.8(1.2)$ & $4.6(1.4)$ & $4.6(1.4)$ & $4.6(1.3)$ \\
\hline Median & 5.0 & 5.0 & 5.0 & 5.0 & 5.0 & 5.0 \\
\hline Range & $2-9$ & $2-9$ & $2-9$ & $2-10$ & $2-9$ & $2-9$ \\
\hline
\end{tabular}


Table 4 Rates of neutrophils and rates of neutropenia before each cycle (population of patients treated with Zarzio ${ }^{\circledR}$ )

\begin{tabular}{|c|c|c|c|c|c|c|}
\hline & $\begin{array}{l}\text { Cycle } 1 \\
N=184\end{array}$ & $\begin{array}{l}\text { Cycle } 2 \\
N=170\end{array}$ & $\begin{array}{l}\text { Cycle } 3 \\
N=165\end{array}$ & $\begin{array}{l}\text { Cycle } 4 \\
N=134\end{array}$ & $\begin{array}{l}\text { Cycle 5 } \\
N=107\end{array}$ & $\begin{array}{l}\text { Cycle } 6 \\
N=98\end{array}$ \\
\hline \multicolumn{7}{|c|}{ Neutrophils $/ \mathrm{mm}^{3}$} \\
\hline Mean (SD) & $4584(3492)$ & 3665 (1897) & $3980(2868)$ & 3239 (1777) & 3389 (1918) & $3601(3494)$ \\
\hline Median & 3969 & 3354 & 3360 & 2890 & 3028 & 3169 \\
\hline Range & $1000-38,219$ & $460-9996$ & $530-27,770$ & $951-12,270$ & $611-11,377$ & $1037-33,830$ \\
\hline \multicolumn{7}{|c|}{ Neutropenia $^{\mathrm{a}}, n(\%)$} \\
\hline Grade 1 & $5(2.8)$ & $18(10.8)$ & $14(8.7)$ & $20(15.3)$ & $14(13.1)$ & $17(17.3)$ \\
\hline Grade 2 & $5(2.8)$ & $16(9.6)$ & $12(7.5)$ & $12(9.2)$ & $11(10.3)$ & $14(14.3)$ \\
\hline Grade 3 & 0 & $1(0.6)$ & $1(0.6)$ & $2(1.5)$ & $4(3.7)$ & 0 \\
\hline Grade 4 & 0 & $1(0.6)$ & 0 & 0 & 0 & 0 \\
\hline MD & 3 & 4 & 4 & 3 & 0 & 1 \\
\hline
\end{tabular}

$M D$ missing data

${ }^{a}$ Grades of neutropenia: Grade 1, [1500-2000[; Grade 2, [1000-1500[; Grade 3, [500-1000[; Grade 4, <500/mm ${ }^{3}$

Table 5 Clinical and

hematological parameters during the follow-up (population of patients treated with Zarzio ${ }^{\circledR}$ )

\begin{tabular}{|c|c|c|c|c|c|c|}
\hline & $\begin{array}{l}\text { Cycle } 1 \\
N=184\end{array}$ & $\begin{array}{l}\text { Cycle } 2 \\
N=170\end{array}$ & $\begin{array}{l}\text { Cycle } 3 \\
N=165\end{array}$ & $\begin{array}{l}\text { Cycle } 4 \\
N=134\end{array}$ & $\begin{array}{l}\text { Cycle } 5 \\
N=107\end{array}$ & $\begin{array}{l}\text { Cycle } 6 \\
N=98\end{array}$ \\
\hline \multicolumn{7}{|c|}{ Body mass index, $\mathrm{kg} / \mathrm{m}^{2}$} \\
\hline Mean (SD) & $26.7(6.0)$ & $26.8(6.2)$ & $26.7(6.1)$ & $27.3(5.9)$ & $27.1(5.5)$ & $26.8(5.0)$ \\
\hline Median & 25.8 & 25.8 & 25.7 & 26.3 & 26.3 & 26.7 \\
\hline MD & 1 & 0 & 2 & 0 & 0 & 3 \\
\hline \multicolumn{7}{|c|}{ Performance status (OMS), $n(\%)$} \\
\hline 0 & $108(63.9)$ & $87(61.7)$ & $82(60.7)$ & $71(65.7)$ & $59(69.4)$ & $49(66.2)$ \\
\hline 1 & $55(32.5)$ & $50(35.5)$ & $48(35.6)$ & $34(31.5)$ & $23(27.1)$ & $25(33.8)$ \\
\hline 2 & $6(3.6)$ & $4(2.8)$ & $4(3.0)$ & $3(2.8)$ & $3(3.5)$ & 0 \\
\hline 3 & 0 & 0 & $1(0.7)$ & 0 & 0 & 0 \\
\hline MD & 15 & 29 & 30 & 26 & 22 & 24 \\
\hline \multicolumn{7}{|c|}{ Temperature, ${ }^{\circ} \mathrm{C}$} \\
\hline Mean (SD) & $37.0(0.2)$ & $37.0(0.1)$ & $37.0(0.2)$ & $37.0(0.1)$ & $37.0(0.2)$ & $37.0(0.1)$ \\
\hline Median & 37.0 & 37.0 & 37.0 & 37.0 & 37.0 & 37.0 \\
\hline MD & 37 & 37 & 36 & 31 & 23 & 25 \\
\hline \multicolumn{7}{|c|}{ Leucocytes $/ \mathrm{mm}^{3}$} \\
\hline Mean (SD) & $7479(5151)$ & 6705 (4835) & $6755(4514)$ & $5960(6128)$ & $6186(4158)$ & $6137(5087)$ \\
\hline Median & 6520 & 5700 & 5800 & 4810 & 5300 & 5100 \\
\hline MD & 1 & 3 & 4 & 4 & 0 & 0 \\
\hline \multicolumn{7}{|c|}{ Lymphocytes $/ \mathrm{mm}^{3}$} \\
\hline Mean (SD) & $1733(760)$ & $1665(788)$ & $1493(691)$ & $1322(549)$ & $1402(709)$ & $1330(871)$ \\
\hline Median & 1586 & 1539 & 1354 & 1271 & 1280 & 1109 \\
\hline MD & 2 & 5 & 7 & 6 & 1 & 0 \\
\hline \multicolumn{7}{|l|}{ Platelets $\times 10^{9} / \mathrm{L}$} \\
\hline Mean (SD) & $279(84)$ & $312(128)$ & $280(110)$ & $279(105)$ & $276(113)$ & $266(80)$ \\
\hline Median & 273 & 284 & 270 & 267 & 259 & 260 \\
\hline MD & 3 & 3 & 5 & 3 & 0 & 1 \\
\hline \multicolumn{7}{|c|}{ Hemoglobin, g/dL } \\
\hline Mean (SD) & $12.8(1.6)$ & $12.0(1.3)$ & $11.7(1.2)$ & $11.6(1.2)$ & $11.4(1.2)$ & $11.2(1.2)$ \\
\hline Median & 12.9 & 12.1 & 11.8 & 11.7 & 11.3 & 11.1 \\
\hline MD & 2 & 4 & 5 & 4 & 1 & 3 \\
\hline
\end{tabular}

$M D$ missing data 
missing data and high RDI ( $>95 \%$ for $83.2 \%$ of patients, all cycles). There are nevertheless some limitations due precisely to the observational and non-stringent conditions of the study. Thus, the primary endpoint (comparison of the incidence of severe neutropenia between cycle 1 and cycle 4) could not be assessed.

Most of the study physicians referred to the EORTC recommendations for primary prophylaxis of febrile neutropenia [13]. According to these recommendations, G-CSF administration is based on an expected risk of febrile neutropenia $\geq 20 \%$ related to the type of chemotherapy. Patient-related risk factors such as age $>65$ years, history of febrile neutropenia, female gender, $\mathrm{Hb}<12 \mathrm{~g} / \mathrm{dL}$ or concomitant hepatic, renal or cardiovascular disease are taken into account for the decision to treat patients with a risk of febrile neutropenia between 10 and $20 \%$.

Half of the study patients were women with breast cancer. Almost half of patients had an age $>65$ years and about one third had a risk of febrile neutropenia $>20 \%$. In this high-risk population, no case of febrile neutropenia was reported. Neutropenia led to hospitalization and/or antibiotic treatment in 10 patients. Even in the absence of control group, these results confirm the efficacy of the prophylactic treatment in patients consecutively included without selection criteria, apart for the indication of prophylaxis with G-CSF.

Analysis of hematological parameters evidences that the rates of neutrophils decreased between cycle 1 and cycle 2 and remained then relatively stable in normal ranges $(>2000$ neutrophils $/ \mathrm{mm}^{3}$ ). These data validate in usual clinical conditions the results of a phase III study that assessed Zarzio ${ }^{\circledR}$ in 170 women with breast cancer; the most important decrease of the rates of neutrophils was also observed after the first cycle of chemotherapy. In the retrospective study of Verpoort and Möhler in 77 patients treated with Zarzio ${ }^{\circledR}$, the efficacy of Zarzio $^{\circledR}$ was comparable to Neupogen ${ }^{\circledR}$; one patient in each treatment group had an episode of febrile neutropenia [19].

The most frequent adverse event related to Zarzio ${ }^{\circledR}$ in our study was pain, more particularly bone pain. These adverse events were expected, and they are considered as very frequent $(\geq 10 \%)$ in the Summary of Product Characteristics of Zarzio ${ }^{\circledR}$ in cancer patients treated with G-CSF [21]. No serious adverse event related to Zarzio ${ }^{\circledR}$ was reported in the 184 study patients. The study discontinuations were most often related to disease progression.

Compared to original filgrastim, Zarzio ${ }^{\circledR}$ has a greater affordability that should encourage the use of G-CSF as recommended by guidelines. Indeed, with the financial constraints on healthcare cost systems, biosimilars offer clinically effective alternative, and Zarzio ${ }^{\circledR}$ should improve access to expensive biological treatments for patients [22]. Moreover, the use and handling of the pre-filled syringes of Zarzio $^{\circledR}$ is easy [23].

In conclusion, this non-interventional study allowed improving knowledge on Zarzio ${ }^{\circledR}$, biosimilar of Neupogen ${ }^{\circledR}$, in current clinical practice. The results obtained in real-life conditions confirm that Zarzio ${ }^{\circledR}$ is efficient and well tolerated in cancer patients.

Acknowledgments We thank the participating patients and study physicians for their sustained commitment to the study. Editorial support was provided by Francis Beauvais.

\section{Compliance with Ethical Standards}

Conflict of interest SN has received honoraria from Amgen, Teva, Roche, Sandoz and Boehringer; MR has received honoraria from Sandoz; MBA has been consultant for Sanofi; RFS and IG are employed by Sandoz Biopharmaceuticals; JLB has received honoraria from Sandoz, Hospira, Teva and Novartis.

Open Access This article is distributed under the terms of the Creative Commons Attribution-NonCommercial 4.0 International License (http:// creativecommons.org/licenses/by-nc/4.0/), which permits any noncommercial use, distribution, and reproduction in any medium, provided you give appropriate credit to the original author(s) and the source, provide a link to the Creative Commons license, and indicate if changes were made.

\section{References}

1. Crawford J, Dale DC, Kuderer NM, Culakova E, Poniewierski MS, Wolff D, Lyman GH (2008) Risk and timing of neutropenic events in adult cancer patients receiving chemotherapy: the results of a prospective nationwide study of oncology practice. J Natl Compr Canc Netw 6:109-118

2. Lyman GH, Delgado DJ (2003) Risk and timing of hospitalization for febrile neutropenia in patients receiving CHOP, CHOP-R, or CNOP chemotherapy for intermediate-grade non-Hodgkin lymphoma. Cancer 98:2402-2409

3. Lyman GH, Morrison VA, Dale DC, Crawford J, Delgado DJ, Fridman M (2003) Risk of febrile neutropenia among patients with intermediate-grade non-Hodgkin's lymphoma receiving CHOP chemotherapy. Leuk Lymphoma 44:2069-2076

4. Timmer-Bonte JN, de Boo TM, Smit HJ, Biesma B, Wilschut FA, Cheragwandi SA, Termeer A, Hensing CA, Akkermans J, Adang EM, Bootsma GP, Tjan-Heijnen VC (2005) Prevention of chemotherapy-induced febrile neutropenia by prophylactic antibiotics plus or minus granulocyte colony-stimulating factor in smallcell lung cancer: a Dutch Randomized Phase III Study. J Clin Oncol 23:7974-7984

5. Vogel CL, Wojtukiewicz MZ, Carroll RR, Tjulandin SA, Barajas-Figueroa LJ, Wiens BL, Neumann TA, Schwartzberg LS (2005) First and subsequent cycle use of pegfilgrastim prevents febrile neutropenia in patients with breast cancer: a multicenter, double-blind, placebo-controlled phase III study. J Clin Oncol 23:1178-1184

6. Wolff D, Culakova E, Poniewierski MS, Lyman GH, Dale DC, Crawford J (2005) Predictors of chemotherapy-induced neutropenia and its complications: results from a prospective nationwide registry. J Support Oncol 3:24-25

7. Cameron D (2009) Management of chemotherapy-associated febrile neutropenia. Br J Cancer 101(Suppl 1):S18-22

8. Hughes WT, Armstrong D, Bodey GP, Bow EJ, Brown AE, Calandra T, Feld R, Pizzo PA, Rolston KV, Shenep JL, Young LS 
(2002) 2002 guidelines for the use of antimicrobial agents in neutropenic patients with cancer. Clin Infect Dis 34:730-751

9. Krell D, Jones AL (2009) Impact of effective prevention and management of febrile neutropenia. Br J Cancer 101(Suppl 1):S23-26

10. Padilla G, Ropka ME (2005) Quality of life and chemotherapyinduced neutropenia. Cancer Nurs 28:167-171

11. Wagner LI, Beaumont JL, Ding B, Malin J, Peterman A, Calhoun E, Cella D (2008) Measuring health-related quality of life and neutropenia-specific concerns among older adults undergoing chemotherapy: validation of the Functional Assessment of Cancer Therapy-Neutropenia (FACT-N). Support Care Cancer 16:47-56

12. Aapro MS, Cameron DA, Pettengell R, Bohlius J, Crawford J, Ellis M, Kearney N, Lyman GH, Tjan-Heijnen VC, Walewski J, Weber DC, Zielinski C (2006) EORTC guidelines for the use of granulocyte-colony stimulating factor to reduce the incidence of chemotherapy-induced febrile neutropenia in adult patients with lymphomas and solid tumours. Eur J Cancer 42:2433-2453

13. Aapro MS, Bohlius J, Cameron DA, Dal Lago L, Donnelly JP, Kearney N, Lyman GH, Pettengell R, Tjan-Heijnen VC, Walewski J, Weber DC, Zielinski C (2011) 2010 update of EORTC guidelines for the use of granulocyte-colony stimulating factor to reduce the incidence of chemotherapy-induced febrile neutropenia in adult patients with lymphoproliferative disorders and solid tumours. Eur J Cancer 47:8-32

14. Lyman GH, Kuderer NM (2010) Prevention and treatment of venous thromboembolism among patients with cancer: the American Society of Clinical Oncology Guidelines. Thromb Res 125(Suppl 2):S120-127

15. Smith TJ, Khatcheressian J, Lyman GH, Ozer H, Armitage JO, Balducci L, Bennett CL, Cantor SB, Crawford J, Cross SJ, Demetri G, Desch CE, Pizzo PA, Schiffer CA, Schwartzberg L,
Somerfield MR, Somlo G, Wade JC, Wade JL, Winn RJ, Wozniak AJ, Wolff AC (2006) 2006 update of recommendations for the use of white blood cell growth factors: an evidence-based clinical practice guideline. J Clin Oncol 24:3187-3205

16. NCCN Clinical Practice Guidelines in Oncology. Myeloid Growth Factors. Version 2.2014. NCCN.org

17. Sorgel F, Lerch H, Lauber T (2010) Physicochemical and biologic comparability of a biosimilar granulocyte colony-stimulating factor with its reference product. BioDrugs 24:347-357

18. Gascon P, Fuhr U, Sorgel F, Kinzig-Schippers M, Makhson A, Balser S, Einmahl S, Muenzberg M (2010) Development of a new G-CSF product based on biosimilarity assessment. Ann Oncol 21:1419-1429

19. Verpoort K, Möhler TM (2012) A non-interventional study of biosimilar granulocyte colony-stimulating factor as prophylaxis for chemotherapy-induced neutropenia in a community oncology centre. Ther Adv Med Oncol 4:289-293

20. Salesi N, Di Cocco B, Colonna M, Veltri E (2012) Biosimilar medicines in oncology: single-center experience with biosimilar G-CSF. Future Oncol 8:625-630

21. Sandoz. Zarzio ${ }^{\circledR}$ (filgrastim). Summary of product characteristics.

22. Gascon P, Tesch H, Verpoort K, Rosati MS, Salesi N, Agrawal S, Wilking N, Barker H, Muenzberg M, Turner M (2013) Clinical experience with Zarzio(R) in Europe: what have we learned? Support Care Cancer 21:2925-2932

23. Tesch H, Indorf M, Rezvani M, Turner M Hexafil: A noninterventional study of the treatment of chemotherapy-induced neutropenia with Zarzio ${ }^{\circledR} /$ filgrastim Hexal ${ }^{\circledR}$. Annual conference of the Deutsche Gesellschaft für Hämatologie und Onkologie (DGHO) Association, 2010 [Poster] 